\title{
DIDACTICS OF LOGIC IN KEN SCHOOLS AND THE CONCEPTION OF LOGICIN THE ENCYCLOPÉDIE OU DICTIONNAIRE UNIVERSEL RAISONNÉ*
}

\begin{abstract}
The paper describes the conception of logic in Polish didactics authored by the Commission of National Education (KEN), an important educational institution of the European Enlightenment. Since the documents of the Commission refer to a vision of science presented by such influential works then as the Encyclopédie ou dictionnaire universel raisonné [Great French Encyclopedia], the paper compares the requirements from the Commission's programmer with the encyclopaedic entries that entail logical problems broadly understood. It turns out that the Commission, following the Encyclopédie, not only recommended a list of textbooks of logic but also shared its eclectic vision of logic. Although it is characteristic of modernity to take a relative approach to the importance of traditional logic, transformed into science on method, or literally an outline of epistemology, understood according to É. Condillac as a specific form of metaphysics, nevertheless some elements of logic were eclectically made valid. This logic, from the times of I. Kant, has been defined as formal logic. Practical logical skills were preferred to the knowledge of logical theories. At the same time attention was paid to the meaning of natural logical skills, and drills in logical reasoning when studying languages and mathematics. Despite preferences for the analytical method they also noticed the importance of synthetic method. It seems also that although the documents of the Commission do not say anything about the teaching of syllogistic issues, in didactic practice inspired by the Encyclopédie in the schools controlled by the Commission, the room was made to teach these problems. Condillac's book was preferred in the schools controlled by the Commission, nevertheless, it was not, as in the case of other textbooks, a must on the reading list, an obligatory reading matter, therefore it was not published in Poland. The conception of logic presented by the Commission as modelled on the Encyclopédie managed to avoid the one-sidedness of Condillac's approach, the approach that in fact eliminated the teaching of logic.
\end{abstract}

Keywords: logic; Great French Encyclopedia; Condillac; d'Alembert

1. Introduction. 2. An entry Logique. 3. Other entries relating to the issues of logic. 4. Conclusions.

* This article was originally published in Polish as: S. Janeczek, Koncepcja logiki w Wielkiej Encyklopedii Francuskiej. Studium z historii recepcji, Studia Philosophiae Christianae 46(2010)2, 5-24. The translation of the article into English was financed by the Ministry of Science and $\mathrm{Hi}-$ gher Education of the Republic of Poland as part of the activities promoting science - Decision No. 676/P-DUN/2019 of 2 April 2019. Translation made by GROY Translations. 


\section{INTRODUCTION ${ }^{1}$}

One of the basic works that largely determined not only the scientific standards of the Enlightenment but also wanted to shape the mentality of the time was the Great French Encyclopedia ${ }^{22}$. In a way typical of the Enlightenment, it was an eclectic work, thus ataxic, but with a clearly defined ideological meaning. For this reason, some of the editions were supposed to unify the sequence of entries in the scientific aspect and partially mitigate the anti-religious character of the Encyclopedia. An example of such an influential edition is a work published by a group of Swiss Protestants under the supervision of an Italian ex-reformer Franceso de Félice (1723-1789), better known by his monastic name: Fortuné Barthélemy ${ }^{3}$.

The literature concerning Encyclopedia, including the topics related to the achievements of individual scientific disciplines, arts and crafts, is extremely rich, however, it is relatively modest in Polish. Therefore, it is time to address, at least in a modest way, selected elements concerning philosophical issues in Encyclopedia, which was written after all by declared philosophers, starting with the logic that was treated during the Enlightenment as a tool for the propagation of a holistically understood mental culture ${ }^{4}$, thus not accidentally constituting such an important element of the reformed education of $\mathrm{KEN}[\mathrm{Na}-$ tional Education Commission] in the spirit of Enlightenment ${ }^{5}$. It also

1 For the methodological status of the "history of reception" see e.g.: J. Garewicz, Kilka uwag o badaniu recepcji filozofii, in: Wybrane zagadnienia z historii filozofii polskiej na tle filozoficznej umysłowości europejskiej, ed. J. Legowicz, Wrocław 1979, 103-107.

2 Encyclopédie ou dictionnaire universel raisonné des sciences, des arts et des métiers, par une societe de gens de lettres. Mis en ordre et publié par ... [Denis] Diderot et quant B la partie mathématique par ... [Jean le Rond] D’Alembert, Vol. I-XXXV, Paris 1751-1780; reprint: Stuttgart 1966-1995; electronic version: Marsanne 1999.

3 Encyclopédie ou dictionnaire universel raisonné de connoissances humaines. Mis en ordre par M. de Félice, Vol. I-LVIII, Yverdon 1770-1780.

4 Cf. S. Janeczek, Z dziejów nowożytnej koncepcji logiki. Od F. Bacona do É. Condillaca, Zeszyty Naukowe KUL (2009)3, 21-33. Cf. Idem, Logika czy epistemologia? Historycznofilozoficzne uwarunkowania nowożytnej koncepcji logiki, Lublin 2003.

5 See: Idem, Jeszcze raz o dydaktyce logiki w oświacie Komisji Edukacji Narodowej. Ujęcie É.B. de Condillaca a przepisy i praktyka szkolna, in: W kierunku filozofii klasycznej 
seems to be interesting to compare the entries from the first edition of this work with those of de Félice to show more fully the context of the creation and reception of this aspect of the Encyclopedia.

\section{AN ENTRY LOGIQUE}

The logical views of the publishers of the Encyclopedia are mostly revealed by the anonymous entry Logique, which is actually a review of achievements and abuse in this field of knowledge, up to the presentation of the best contemporary textbooks. It has been thoroughly reworked by de Félice but without major changes in its substance ${ }^{6}$. According to Voltaire's opinion regarding this edition, it is better edited, it has a clear systematic and historical part. In the first case, it eliminates a rhetorical "excursion" against scholastic philosophy which presents out of context and hence bizarre issues raised in this philosophical tradition. Instead, it incorporates a clear and balanced, thus an encyclopedic statement by d'Alemberto on the nature of logic, taken from Essai sur les élements de philosophie, ou sur les principes des connaissances humaines ${ }^{7}$. Similarly, it removes the final batch, which is to a large extent a reprint of the elements of the so-called second logic (written in the form of scholastic exercises) of the reformer of Jesuit education in France, popularising in this field the work of Locke and Claude Buffier, who tried to combine modern and scholastic traditions ${ }^{8}$. It also completes an overview of the Enlightenment manuals of logic, reproduced by the original edition following the above-mentioned manual by Buffier?

inspiracje i kontynuacje. Księga jubileuszowa ofiarowana Profesorowi Edwardowi Nieznańskiemu, eds. J. Krokos, K. Świętorzecka, R. Tomanek, Warszawa 2008, 471-483.

6 Logique, in: Encyclopédie ou dictionnaire universel raisonné des sciences, des arts et des métiers, op. cit., vol. IX, 637-641; Logique, in: Encyclopédie ou dictionnaire universel raisonné de connoissances humaines, op. cit., vol. XXVI, 507-513.

7 The outline of philosophy was published in the fourth volume of Mélanges de litterrature, d'histoire et de philosophie (Amsterdam 1759); also published as Oeuvres complètes de d'Alembert, ed. A. Belin, vol. I, Paris 1821 (reprint: Genève 1967), 152-155.

8 See: S. Janeczek, Z dziejów dydaktyki logiki w szkołach KEN. Claude Buffier SJ, Roczniki Filozoficzne 56(2008)2, 83-99.

9 C. Buffier, Les principes du raisonement exposés en deux logiques nouvéles avec des 
Already at the first reading, one can notice the eclectic nature of the concept of logic in both approaches to the word Logique. On the one hand, it seems that it refers to Buffier, who, in a traditional spirit, values logic for providing les vrais principes du raisonement and maintains its trimodal system as an operation to create concepts, to make judgements and a proper way of thinking; however, in a rather modern spirit, he believes this time that logic should "provide us with rules so that our thoughts are always right" ${ }^{10}$. According to the author of the encyclopaedic entry, logic is "the art of right thinking" and thus according to the Cartesian tradition ${ }^{11}$, or the art of appropriate use of our mental abilities according to the three operations of traditional logic, processed - similarly to what was often done by the logicians belonging to the so-called second scholasticism - in the spirit of the rhetorical tradition of the Renaissance, as operations of defining, sharing and understanding ${ }^{12}$. At the same time, he evokes the modern four-segment arrangement of its lecture, because "to think correctly is to perceive well, to judge well, to reflect well, and to combine ideas methodically"; while, although he described the third operation in the spirit of humanism as discours ${ }^{13}$ he ac-

ramarques sur les Logiques qui ont eu le plus de réputation de notre temps (Paris 1714); quoted as: Traité des premieres veritez de conséquence, ou les principes du raisonement, in: Cours de sciences sur des principes nouveaux et simples, pour former la langage, l'esprit et le coeur dans l'usage ordinaire de la vie (Paris), 1732 (reprint: Genève 1971), 745-892; reprinted fragments are in Buffier's work, columns 781-782, 885-888.

10 C. Buffier, Traité des premieres veritez de conséquence, ou les principes du raisonement, in: Idem, Cours de sciences, op. cit., 747.

11 See the title term for logic in: A. Arnauld, P. Nicole, La logique, ou l'art de penser contenat, outre les regles communes, plusieurs observations nouvelle propres à former le jugement, par le Sieur le Bon, Paris 1662; quoted in critical edition P. Clair, F. Girbal, according to Paris 1683 - Paris 1965 edition; also: Logika, czyli sztuka myślenia, transl. S. Romanowa, Warszawa 1958.

12 E.g. S. S. Makowski, Cursus philosophicus iuxta veram Aristoetelis, philosophorum principis doctrina in alma universistate cracoviensi luci publicae porrectus, vol. I. Cracoviae 1769, 2, 15. See: S. Janeczek, Logika czy epistemologia?, op. cit., $136 f$.

13 "La logique est l'art de penser juste, ou de faire un usage convenable de nos facultes rationelles, en définissant, en divisant, et en raisonnent ... la pensée n'est autre chose qu'une espece de discours intérieur et mental, dans lequel l'esprit converse avec lui- 
tually operated with a broad category of reasoning (raisonnement) or even a proof (démonstration). It naturally resembles an arrangement which was mostly popularised by Cartesian La Logique ou l'art de penser, according to which logical operations are reduced to: (1) "presenting (concevoir) something to ourselves", which is "a simple vision (la simple vøe) of things appearing to our mind" in the form of ideas (idée); (2) judgements (juger), that is, "combining different ideas", by means of which we "we claim that the one is the other one, or we deny that the one is the other one"; (3) reasoning (raisonner), in a form of "a judgment out of few others"; and (4) ordering (ordonner), also referred to as a method (methode) which is "the activity of our mind thanks to which, while having different ideas, different judgments and reasonings relating to the same object ... we arrange (disposer) the most appropriate way to get to know this object"14.

At the same time, the entry Logique quotes F. Bacon's understanding of logic, whose classification of sciences was referred to by Encyclopedia ${ }^{15}$. The basic aims of logic, according to Bacon, are to be reduced to four functions of reasoning (raisonner), reflecting the process of a discovery (trouver ce quil cherche), consideration of what was discovered (raisonner de ce quil atrouve), remembering the judgment that was made (retenir ce quil aretenu) and finally, teaching others of what was remembered (enseigner aux autres ce quil a retenu). No wonder that the branches of this art of reasoning, which is still traditionally defined - according to the concept of Aristotle, who claimed it to be a tool of organizing the acquired knowledge - is the art of searching or inventing that is close to modernity (l'art de la recherche ou de l'invention), that is the logic of a scientific discovery. He also overestimates the importance of the art of

mme ... . Comme pour penser juste il est nécessaire de bien appercevoir, de bien juger, de bien discourir, et de lier méthodiquement ses idées; il suit de là que l'apprehension ou perception, le jugement, le discours et la méthode, deviennent les quatre articles fondamentaux de cet art" (Logique, in: Encyclopédie ou dictionnaire universel raisonné des sciences, des arts et des métiers, op. cit., 507-508).

14 A. Arnauld, P. Nicole, Logika, czyli sztuka myślenia, op. cit., 39-41; see: S. Janeczek, Logika czy epistemologia?, op. cit., $279 \mathrm{f}$.

15 On the position of F. Bacon to logic see: ibid, $166 f$. 
evaluation or judgement (l'art de l'examen ou de jugement), retention or memory (l'art de retenir ou de la mémoire), eloquence or speaking (l'art de l'élocution ou de s'énoncer), whose interchangeable nomenclature proves the continuation of the rhetorical tradition (e.g. invention), as well as its modification (e.g. recherchere). The reference to Bacon also explains a strong aversion to scholastic logic, since it was to be "overused", hence "it lost the credit of trust" [which was due to it]. Using common stereotypes intensified in the Enlightenment, the "school" logic was to be "loaded with terms and barbaric sentences" or so "sunk in the sea of dry and vain subtleties" that, in fact, it lost its basic purpose. In the place of "supporting the art of right thinking" it has become "an art whose aim is to train the mind in disputes and discussions". No wonder that "logic was only the art of words which frequently made no sense at all, and served only to hide ignorance, not to improve judgments; to amuse reason, not to strengthen it; and finally to distort reality, not to explain it" ${ }^{\text {"16 }}$.

The author of the slogan Logic refers to the modern tradition in a completely different way. This is already visible in the admiration of Descartes, who is, however, more valued on the grounds of postulates concerning the new method (the requirement of precision (précision) and accuracy (justesse) than on the grounds of philosophical solutions ${ }^{17}$. After all, he appreciates J. Locke more highly, whose work is supposed to relate to Descartes' and Malebranche's achievements almost the same as a story relates to a novel. His credit is primarily to make a thorough analysis of our mind's operations ${ }^{18}$. However, he seems to value Condillac's achievement the most. Condillac, assimilating the themes of Locke's descriptive psychology with the principles of the mental function, showed the ways of achieving all the knowledge available to us in an incomparably more concise, clearer and more precise way than Locke himself. In fact,

16 Logique, in: Encyclopédie ou dictionnaire universel raisonné des sciences, des arts et des métiers, op. cit., vol. IX, 637-638; Logique, in: Encyclopédie ou dictionnaire universel raisonné de connoissances humaines, op. cit., vol. XXVI, 508.

17 See: S. Janeczek, Logika czy epistemologia?, op. cit., 178-255.

18 Ibid, 362-462. 
however, by exposing the role of the algebraic method, he has led to the elimination of teaching of logic from practice transforming it into epistemology in a proper handbook of logic, which was written for schools over time $\mathrm{KEN}^{19}$. It is not a coincidence, therefore, that de Félice has significantly shortened the arguments concerning Condillac which presented, in a closer way, the principles of epistemology of this author who was praised, in the original text, for the role of language in cognition, especially the method of analysis, considered to be "the simplest, the clearest and most prolific principle, thanks to which the human mind has its progress for centuries, even if its influence has remained unnoticed"20.

It is not a coincidence that both editions of the Encyclopedia value the most the approaches that are not only of high methodological value but also, with their whole eclecticism combine the traditional logic with modern epistemology, they prefer, above all, textbooks related to modern empirical tradition ${ }^{21}$. This was probably the reason why this excellent textbook, which was Port-Royal Logic by A. Arnauld and P. Nicole, was mentioned only in the context of assimilations of the thoughts of Descartes ${ }^{22}$. In turn, the textbooks of Jean Le Clerc (Clericus) ${ }^{23}$ or Buffier's were an important medium of popularising the views of Locke on the continent. It is not a coincidence that the Encyclopaedia aspiringly criticises a textbook of J.P. de Crousaz ${ }^{24}$, who

19 La Logique ou les premiers développements de l'art de penser, Paris 1780 (see as: Logika czyli pierwsze zasady sztuki myślenia, dzieło elementarne... na żądanie bywszej Komisji Edukacyjnej Narodowej dla szkół publicznych napisane i od niej aprobowane, a teraz z przydatkiem niektórych objaśnień i przypisów przez Jana Znoskę z francuskiego na polski język przełożone, Wilno 1802, 1819³; (new edition: ed. T. Kotarbiński, Warszawa 1952). See: S. Janeczek, Logika czy epistemologia?, op. cit., $462 f$.

20 Logique, in: Encyclopédie ou dictionnaire universel raisonné des sciences, des arts et des métiers, op. cit., vol. IX, 638-639; Logique, in: Encyclopédie ou dictionnaire universel raisonné de connoissances humaines, op. cit., vol. XXVI, 511-512.

21 Ibid, 512-513.

22 See: S. Janeczek, Logika czy epistemologia?, op. cit., $279 f$.

23 Logica sive ars ratiocinandi. Logica, Ontologia, Pneumatologia, vol. I-II, Amstelodami 1692. See: S. Janeczek, Z dziejów nowożytnej koncepcji logiki. Propagatorzy poglądów J. Locke'a, Kwartalnik Filozoficzny 36(2008)4, 102-105.

24 Système de Reflexion qui peuvent contribuer à la nettetê et à l'étendue de nos 
underestimates the achievements of Locke ${ }^{25}$. In this perspective, one can understand the assessment of the approach of Christian Wolff that is more than vague and is limited to quoting the title of his much appreciated and more extensive version of Latin logic, which is also supposed to be an expression of a reduction of principles and rules of logic to evidence, but - what the entry is silent about - tries to maintain a balance between the reasonable and empirical tradition ${ }^{26}$. The edition of de Félice does not differ from the original version and it removes the information about the textbook of Jesuit Buffier, which is the basis for reviewing those books, it also adds three other items to the characteristics of modern logic books. Pointing to his own study ${ }^{27}$, he refers to the achievements of Isaac Watts ${ }^{28}$ and Antonio Genove$\mathrm{si}^{29}$, which also belonged, however, to the empirical tradition of Locke. In his own study, he emphasises, above all, the ability to separate theory from science practice, in morality and social life. However, it seems that it was the harmonious combination of those dimensions that was supposed to determine the value of that achievement, an example of which can be found in Discours sur la maniere de former l'esprit et le coeur des enfans. This tendency is consistent with the common-sense practice of combining logic, as easily explained as possible, with the

connaissances, ou Nouvel Essai de Logique, Amsterdam 1712. See: W. Risse, Die Logik der Neuzeit, vol. II, 1640-1780, Stuttgart 1970, 546-549; W. S. Howell, Eighteenth-Century British Logic and Rhetoric, Princeton 1971, 304-331.

25 Logique, in: Encyclopédie ou dictionnaire universel raisonné des sciences, des arts et des métiers, op. cit., vol. IX, 639; Logique, in: Encyclopédie ou dictionnaire universel raisonné de connoissances humaines, op. cit., vol. XXVI, 508.

26 Philosophia rationalis sive logica, methodo scientifica pertractatum ad usum scientiarum atque vitae aptata, Francofurti 1728 (edition of 1740 published by J. École'a Hildesheim 1984). See: S. Janeczek, Logika czy epistemologia?, op. cit., $306 f$.

27 Leçons de logique, vol. I-II, Yverdon 1770.

28 Logic, or the Right Use of Reason in the Inquiry after Truth with a Variety of Rules to Guard against Error in the Affairs of Religion and Human Life, as well as in the Sciences, London 1725 (reprint, published in London 1847 - Morgan, PA 1996). See: S. Janeczek, Źródła logiki Jana Śniadeckiego. F. Dalham’s i I. Watts’s textbooks, in: Gaudium in litteris. Księga pamiątkowa ku czci Księdza Arcybiskupa Stanisława Wielgusa, ed. S. Janeczek et al., Lublin 2009, 613-621.

29 Elementorum artis logico-criticae libri V, Venetiis 1745, Varsaviae 771. See: S. Janeczek, Z dziejów nowożytnej koncepcji logiki. Propagatorzy poglądów J. Locke’a, op. cit., 102-105. 
practice of life what was typical for the Enlightenment and what has been revealed since Locke's times, and was typical, for example, for popular works of the Marquis J. B. d'Argens ${ }^{30}$.

A more serious modification made by de Félice in the entry Logique was (already signalled) the removal of Buffier's remarks about the nature of logic, taken from his so-called second logic, which deals with issues that remain under consideration within traditional logic. By posing (together with scholastics) the problem of whether logic is necessary to achieve perfection in any science, it limits the importance of so-called artificial logic, i.e. logical theory, indicating that the level of practical logical improvements is determined by the aspect differentiation of the level of natural abilities. The relative value of rules of logic is also to be indicated by the very discovery of logic, which took place without knowing its rules. Buffier, referring these theses to the logic discovered by Aristotle, supported by scholastics, refers to the example of geometricians who practice their science independently of the knowledge of rules of logic. In this place, he exposes the role of the so-called natural logic (i.e., natural logical equipment) and natural mind training ${ }^{31}$.

These remarks regarding the need for a study of logic can be compared with d'Alembert's laconic considerations contained in Essai sur les Eléments de philosophie from 1759, hence probably known to the author of the original encyclopaedic entry from $1765^{32}$. De Félice, after all the author of a logic textbook, inserted them in place of impertinent remarks on scholastic logic, contained in the original entry Logique. Admittedly, d'Alembert, in line with modern tradition, questions the need to become familiar with a logical theory which, like the

30 La philosophie du bon sens, ou reflexions philosophiques sur l'incertudine des connoissances humaines, à l'usage des cavaliers et du beau sexe, Paris 1737. See: W. Risse, Die Logik der Neuzeit, op. cit., vol. 2, 522-524.

31 Logique, in: Encyclopédie ou dictionnaire universel raisonné des sciences, des arts et des métiers, op. cit., vol. IX, 639; C. Buffier, Traité des premieres veritez de conséquence, ou les principes du raisonement, in: Idem, Cours de sciences, op. cit., 781-782, 885-888.

32 Logique, in: Encyclopédie ou dictionnaire universel raisonné Encyclopédie ou dictionnaire universel raisonné de connoissances humaines, op. cit., vol. XXVI, 508-510. 
knowledge of ethical treaties, is not necessary to become an honest human being. Similarly, the geometricians, "having only the natural sense as their guide, get to the most hidden and abstract truth". It also limits the basic task of logic, i.e. the concern for proper formulation of truths of a material nature, in the form of examining the relations that take place between ideas, following Locke's and Condillac's footsteps ${ }^{33}$. However, he appreciates, among other things, the attention paid to the precision of the terms used, the appropriate approach to the object (analytical), or the proper linking of successive truths, which in the first case seems to be a result of e.g. Port-Royal Logic, emphasizing, after B. Pascal, the need to define terms, and in the last two cases it is the fulfilment of the Cartesian intertwining of analysis and synthesis, recommended for example by Port-Royal Logic ${ }^{34} \mathrm{At}$ the same time, pointing to our cognitive limitations, in relation to which we are doomed to actually use only probable knowledge, he postulates supplementing of traditional logic with the art of conjecture (art de conjecturer), which was close to the calculus of probability then discov$\operatorname{ered}^{35}$. Despite the aforementioned leaning towards the method used by modern mathematicians ${ }^{36}$, d'Alembert, who not only was a mathematician himself but also used speculative methods (constructivism) in physics following Descartes' steps, is quite sceptical about the possibility of mathematising of all knowledge ${ }^{37}$.

All in all, therefore, the author of the original slogan Logic, following d'Alembert's footsteps, accentuates epistemological themes in the lecture of logic, but in a way characteristic of most textbooks, not only of 17 th ones but also of those from the 18th century, his

33 Ibid, 509.

34 See: S. Janeczek, Logika czy epistemologia?, op. cit., 260-261, 300.

35 See: Historia matematyki od czasów najdawniejszych do początku XIX stulecia, vol. II, in: Matematyka XVII stulecia, ed. A. P. Juszkiewicz, transl. S. Dobrzycki, Warszawa 1975, 90-107.

36 See: H. W. Arndt, Methodo scientifica pertractatum. Mos geoemetricus und Kalkülbegriff in der philosophischen Theorienbildung des 17. und 18. Jahrhunderts, Berlin 1971.

37 See: S. Janeczek, Teoria nauki w ujęciu J. le Ronda d'Alemberta. Między empiryzmem, racjonalizmem i intuicjonizmem, in: Philosophia vitam alere. Prace dedykowane Profesorowi Romanowi Darowskiemu SJ, ed. S. Ziemiański, Kraków 2005, 199-212. 
approach is eclectic. He sees the value that shapes the rules of traditional logic. Above all, however, he points to the importance of natural logical equipment as well as to the importance of the material basis of knowledge, obtained through empirical research and then processed using the principles o logic-epistemology that is broadly understood, moving away, however, from the seventeenth-century belief in the universality of the "mathematical method" as a method of reasoning of demonstrative nature.

However, one must not forget that the analyses of other statements of d'Alembert, even those contained in the entry Collège, allow us to see a more narrow vision of logic that was supposed to be compulsory for the reformed secondary education. In there, It radicalises a modern tendency of transforming logic into epistemology, which is supposed to be the basic science of philosophy, thus following de Condillac it becomes a specific metaphysics (oriented associatively $)^{38}$. In that case, d'Alembert limits logical-philosophical education to "a few lines of logic" (dans la philosophie, on borneroit la logique à quelques lignes) and to a presentation of "Locke's outline", that is, in fact, the specificity of the principles of functioning of mind that was shown by him and what was considered to be a manifestation of valuable metaphysics (la métaphysique à un abrégé de Locke) ${ }^{39}$.

The descriptions of the entry Logic in both versions of Encyclopedia are quite general and eclectic, or even inconsistent. On the one hand, they prefer to take care of material knowledge rather than to take care for the form of reasoning, because they emphasise that they were

38 J. le Rond d'Alembert. Essai sur les Eléments de philosophie, op. cit., 180-181. See: S. Janeczek, Przejawy refleksji metafizycznej w filozofii Étienne'a Bennota de Condillaca (1715-1780), in: Z dziejów filozoficznej refleksji nad człowiekiem. Księga pamiątkowa ku czci Profesora Jana Czerkawskiego (1939-2007), eds. P. Gutowski, P. Gut, Lublin 2007, 257-274; Idem, Z dziejów nowożytnej koncepcji logiki. J. le Rond d’Alembert, Roczniki Kulturoznawcze 4(2013)1, 51-82.

39 Collège, in: Encyclopédie ou dictionnaire universel des sciences, des arts et des métiers, op. cit., vol. III, 634-637 (pedagogical part). Rewritten entry Collège in: Encyclopédie ou dictionnaire universel raisonné Encyclopédie ou dictionnaire universel raisonné de connoissances humaines, in part devoted to meurs et religion (op. cit., vol. $X, 334-338)$, repeats d'Alembert's findings on philosophical and logical education. 
rooted in natural logical endowment and prefer to care for the formation of a practical logical culture rather than to care for teaching logical theory, useful both in a purely scientific and practical sphere. On the other hand, however, they see the need to teach logic and to teach it in the form of textbooks. At the same time, they consolidate the Cartesian tendency to transform logic into a science of a method, thus they introduce into it the issue of epistemology with a clear preference for the arrangements characteristic for empiricism which aims at discovering the mechanisms of functioning of the human mind which constitute the foundation for the rules of logic that result from them.

\section{OTHER ENTRIES RELATING TO THE ISSUES OF LOGIC}

This shift of emphasis from the issue of logic to the issue of a method explains the importance which the Encyclopedia gives to this issue, starting with the entry Méthode (a logical and mathematical part) that was written by d'Alembert. No wonder that it is a great proclamation of the method used by mathematicians ${ }^{40}$, mainly in the spirit of Wolff ${ }^{41}$ who was to prove (also in practice) that this method was not only "natural for human mind" (naturelle l'esprit bumain), but also that it allowed to discover the truths of all kinds (qui fait découvrir les verités de tout genre) and it was, therefore, a "method of all sciences" (la méthode mathématique étoit celle de toutes les sciences) and thus enabled to achieve high epistemological standards, or certitude (certitude). As it was in the case of mathematics. However, in the case of the entry Logique, d'Alembert not only draws atten-

40 Méthode, in: Encyclopédie ou dictionnaire universel raisonné des sciences, des arts et des métiers, op. cit., vol. X, 445-446.

41 The understanding of a mathematical method of proving considered as a method of philosophy, was best formulated by Wolff in Kurtze Unterricht von der mathematischen Methodewhich starts with Anfangsgründe aller mathematischen Wissenschaften (Halle 1710; Polish translation and comments: R. Kuliniak, T. Małysz, XVII i XVIII-wieczne popularne podręczniki studiowania matematyki. With particular emphasis on "Krótki wykład o matematycznej metodzie nauczania", in: Oblicza filozofii XVII wieku, ed. S. Janeczek, Lublin 2008, 335-356). Cf. S. Janeczek, Logika czy epistemologia?, op. cit., $311 f$. 
tion to the limitations of the use of this method which he identifies with the evidence procedures (démonstration) but he also postulates a contribution of knowledge in the form of a chain of evidence, in which successive sentences are not only explained but are also validated in the preceding sentence, he emphasises the role of the primary principles of this chain of thoughts (toute science repose sur certains principes). Hence, they should be sufficiently proven (tous les principes soient suffisamment prouvés) that is to say, they should be distinguished by the requirements of certitude et évidence. The value of that statement depends on the material value of the individual elements of this chain of evidence, what relativizes the meaning of resulting techniques in a way that is typical for modern times.

In this context, there appears the issue of preference for one of the two methods discussed in the manuals of logic from that time. In the case of the edition published by de Félice, the preference for the analytical method seems to dominate, since he modifies the entry Méthode (a logical part) by reprinting the extracts: O pochodzeniu poznania ludzkiego [On the origin of human cognition] by É. Condillac, which is an enthusiastic proclamation of this method treated as a universal method, that is a method of discovering the truth as well as teaching $\mathrm{it}^{42}$. The universality of the analysis results from the fact that it corresponds to the nature of a human mind, which is important not only in terms of discovering the truth but also in terms of teaching it because, in order to present the truth in the most perfect order, it is necessary to notice the order in which it was naturally discovered.

On the other hand, one can notice a preference for analysis also in the original version of the Encyclopedia. This is revealed in the entry L'Analyse en Logique written by a Jesuit Claude Yvon who worked on the Encyclopedia $a^{43}$ and who strongly advocated a preference of the analysis in the spirit of Condillac, hence it is not a coincidence that a Polish translator of the textbook of Logic by Condillac included this

42 Méthode, in: Encyclopédie ou dictionnaire universel raisonné de connoissances humaines, op. cit., vol. XXVIII, 538-548.

43 In: Encyclopédie ou dictionnaire universel raisonné des sciences, des arts et des métiers, op. cit., vol. I, 401-403. 
article as an appendix to this work ${ }^{44}$. Supporting Condillac, he describes it as a universal method of discovery and teaching, interpreted in the sense of genetic associationism (consistent with the nature of our mind) in the form of a specific calculation constituting a process of decomposing and composing of concepts in order to compare them (which was traditionally described as synthesis) thus precisely revealing the relationship between them. A more balanced assessment of the analysis is presented this time by de Félice, who, in the spirit of Descartes, despite treating the analysis as la méthode la plus naturelle it is however only la plus fore for parvenir la découverte de la vérite, thanks to the plus claire at plus precise approach to ideas ${ }^{45}$.

However, a specific counter-proposal for the slogan Analysis is d'Alembert's article titled Analytique, published in both editions, which treats the method of analysis and synthesis in a complementary way, stating that in the philosophy of nature and mathematics regarding the solving of difficulties one should start from the application of the analytical method, and then only move on to the synthetic method [il faut commencer à applanir les difficultés par la méthode analylique, avant que d'en venir à la méthode synthétique]. At the same time, he certainly identifies the analysis with the empirical-inductive method (in the sense of inductive generalization of data obtained from experience and observation ${ }^{46}$ ).

Eclecticism revealed in the analysis of the entry Logic in terms of the needs and tasks of this discipline (art) is also revealed in the approach of the Encyclopedia to the question that concerns the need to define precise reasoning procedures, that is the last element of the three-part logic. It is not different in the anonymous slogan Raisonnement, which treats this concept in categories of operation on ideas,

44 La Logique ou les premiers développements de l'art de penser, Paris 1780 (Logika czyli pierwsze zasady sztuki myślenia, dzieło elementarne..., op. cit., 163-169).

45 In: Encyclopédie ou dictionnaire universel raisonné de connoissances humaines, op. cit., vol. II, 491-495.

46 Encyclopédie ou dictionnaire universel raisonné des sciences, des arts et des métiers, op. cit., vol. I, 403-404; Encyclopédie ou dictionnaire universel raisonné de connoissances humaines, op. cit., vol. II, 501-502. 
that is characteristic of modernity, although known in general terms ${ }^{47}$. The Encyclopedia will define reasoning as the operation of checking ideas, i.e. whether two ideas are compatible with or contradictory to each other, by means of the third idea or other ones. At the same time, it relativizes the meanings of the procedures of reasoning understood in such a way, since the perceptions of relations between ideas are to be obvious, and, hence, it is impossible for every person not to reason in a proper (right) way. This statement justifies, on the one hand, the relativization of the reasoning procedures developed in the history of logic, considered to be over-expanded and useless knowledge (entierement superflu et de nul usage); on the other hand, it leads to - as signalled above - the postulate of taking care of material knowledge, as it is the errors at this level that are primarily the reason for erroneous reasoning. No wonder that this slogan concerns errors in consistently epistemological categories, from errors resulting from inadequate functioning of cognitive organs to imprecise language.

Those views can also be found in the entry Rozumowanie [Reasoning] in the edition of the Encyclopedia by de Félice ${ }^{48}$. First of all, it seems to be a manifestation of the eclectic continuity of the criteriological arguments reaching as far as Descartes, and even more associationist psychology of cognition by Locke who valued the intuitive approach as more important than the discursive one and thus tried to present it as a sequence of intuition ${ }^{49}$. After all, this approach is also typical for Condillac ${ }^{50}$, following which de Félice

47 Raisonnement, in: Encyclopédie ou dictionnaire universel raisonné des sciences, des arts et des métiers, op. cit., vol. XIII, 776-778.

48 Raisonnement, in: Encyclopédie ou dictionnaire universel raisonné Encyclopédie ou dictionnaire universel raisonné de connoissances humaines, op. cit., vol. XXXVI, 82-85.

49 Although both Descartes and Locke were also far from overestimating their concern for discursive procedures, they attempted to validate them by treating the sequence of reasoning as a sequence of intuitions. See: S. Janeczek, Logika czy epistemologia?, op. cit., 98-210, 391-401.

50 Condillac states that "the unknown truth cannot be discovered - only as much as it is contained in known truths" ["on ne peut découvrir une vérité qu'on ne connait pas, qu’autant qu'elle se trouve dans des vérités qui sont connues"] (É. Condillac. Logika, op. cit., 137; Idem, Logique, in: Oeuvres philosophiques de Condillac, op. cit., vol. II, 409). 
reduced reasonings to the "art of deducting of one statement from the other one" enabling "drawing of unknown truths from the truths that are already known" 51 . On the other hand, what Condillac valued the most, was the so-called obviousness of reasoning (évidence de raison) reduced to operations modelled on an algebraic analysis, subordinated to exploratory operations. He listed two types of sentences distinguished by obvious reasoning; the first one is to be self-evident and the second one is to be a result of another statement which is self-explanatory; the specificity of the former type of a sentence was intended to make it possible to establish its identity in a direct way (immédiatement) while the identity of the latter type of a sentence is only discovered indirectly ${ }^{52}$. De Félice, seems to combine this concept - ignoring only the dazzling category of identity which was typical for Condillac - with Cartesian logic when he states that this deduction is sometimes immediate (immédiate) and defining it after Descartes as intuitive reasoning (intuitif) ${ }^{53}$. At the same time, just like Condillac who considered the intuitive cognition as the exclusive way of cognition typical for God, while us - due to cognitive limitations - are doomed to indirect reasoning, de Félice states that the weakness of our mind when it comes to the intuitive cognition (intelligence) makes it necessary while referring to things that are more complicated for us or less known to us (choses moins simples ou moins connues) while comparing two ideas we do not see clearly their similarities or differences or mutual relations that is, we cannot make any intuitive judgment about them, to make proper reasoning

51 "Raisonnement ..., logique, ce, c'est l'art de déduire une proposition d'une autre, de tirer des vérités inconnues de vérités connues" (Raisonnement, in: Encyclopédie ou dictionnaire universel raisonné de connoissances humaines, op. cit., vol. XXXVI, 82).

52 See: S. Janeczek, Kartezjanizm teorii nauki É. Condillaca, in: Filozofia XVII wieku i jej kontynuacje, ed. Z. Drozdowicz, Poznań 2009, 203-209.

53 Intuitus mentis, the condition of which is the analytical reduction of the object to a simple form, which will enable its intuitive grasp. R. Descartes, Regulae ad directionem ingenii, Amstelodamii 1701; Idem, Oeuvres de Descartes, eds. C. Adam, P. Tannery, Paris 1897-1913; reprint: 1996, vol. X, 366; Idem, Prawidła kierowania umysłem, in: Prawidła kierowania umysłem. Poszukiwanie prawdy poprzez światło przyrodzone rozumu, op. cit., Warszawa 1937, 1958², 23. 
which is, out of necessity, an auxiliary ability of human mind (une faculté subsidiaire de l'entendement). At the same time, de Félice eclectically identifies nature which is understood in an epistemological way, with the broadly understood syllogistics, trying to simplify its principles even more than Port-Royal Logic ${ }^{4}$.

A special kind of an associationist concept of reasoning is to be syllogism. The anonymous author of an encyclopaedic entry devoted to this issue - it is worth noting that it is relatively extensive one - on the one hand, he presents an objectified outline of traditional syllogism, on the other hand, however, he formulates a basic, though a rather shorter one, criticism of it, formulated in the perspective of the method of asking about the right means of discovering the truth, fundamental for modern considerations, which were valued higher than the methods of organizing knowledge and teaching it ${ }^{55}$. In its basic form, the entry $S y l-$ logisme refers directly to a criticism of syllogism done by Locke, recalling the French translation of the basic work of the British empiricist ${ }^{56}$. The syllogism is not an indispensable cognitive tool, since real-life practice shows that people conclude clearly, accurately and precisely (net, justes, et précis) without even knowing the principles of logic in the slightest degree, and they are even able to notice the imperfection and falsity of the long and complicated arguments to which they are exposed by experts in logic. "Experience, action and our thoughts" teach us to deduce in a correct way better than any rules do. Thus, ironically speaking, he indicates that peasants have more common sense when it comes to everyday life than the doctors of Sorbonne. The needlessness of the knowledge of syllogistics is also indicated by the history of science and social life, even with reference to mathematics,

54 Cf. A. Arnauld, P. Nicole, Logika, czyli sztuka myślenia, op. cit., 16-17, 19-21, 257-265, 294-304; Idem, La logique ou l'art de penser, op. cit., 21-22, 24-25, 182-188, 211-217.

55 Syllogisme, in: Encyclopédie ou dictionnaire universel raisonné des sciences, des arts et des métiers, op. cit., vol. XV, 719-725.

56 The entry refers to Chapter XVII of Part Four: J. Locke, Rozważania dotyczące rozumu ludzkiego, transl. B. Gawecki, Warszawa 1955, vol. II, 414-431; Idem, An Essay Concerning Human Understanding, London 1690, actually 1689; quoted from: The Works of John Locke, London $1823^{3}$ (reprint: Aalen 1963), vol. III, 115-127. See: S. Janeczek, Logika czy epistemologia?, op. cit., 434-455. 
which, using the evidentiary procedures, lacks syllogistics. Syllogism does not contribute to showing whether it is possible to strengthen the link between interrelated thoughts through natural, mental improvement. Moreover, the use of syllogism slows down investigation to inference effect. The mind can see more accurately thanks to its own insight, when it is certain and used to thinking, than when it is darkened, blocked or forced by syllogistic forms. Hence, "the art of syllogism is not the quickest, simplest and most convenient means of discovering and showing the truth". What is more, it is not even useful for discovering the misconceptions hidden in complex rhetorical figures, to which - let us add - even Descartes and Locke agreed, who transferred the didactics of syllogistic to the teaching of rhetoric ${ }^{57}$.

A more balanced evaluation of sylogistics is presented by the entry Syllogisme in the publication of de Félice ${ }^{58}$. It not only recalls some of the principles of the chapter of part III Port-Royal Logic but he also states that "drifting away from them [those rules - S.J.] causes a risk of misunderstanding and confusing an error with the truth". At the same time, however, he relativises their meaning, stating that those technical rules, even mechanical, do not teach reasoning, and only in some cases can ease the memory in scholastic discussions. Everyday experience is supposed to teach that even in nine hundred and ninety-nine cases per thousand, people are capable of reasoning correctly and making right judgments (qui raisonnent consequemment, et qui jugent tros bien) never dealing with the art of syllogism. However, this does not mean a total negation of the usefulness of studying logic, just as it is with the usefulness of studying grammar. Although people speak the language without knowing its rules, this does not mean that it is useless to study it. No wonder that he distances himself from the negative opinion that is often formulated about the need to know the rules of syllogism, which are supposed to be useless even in solving false reasoning or rejecting suggestive

57 E.g. rule X - R. Descartes, Prawidła kierowania umysłem, op. cit., 47-51; Idem, Regulae ad directionem ingenii, in: Oeuvres de Descartes, op. cit., vol. X, 403-406.

58 Encyclopédie ou dictionnaire universel raisonné de connoissances humaines, op. cit., vol. XXXIX, 624-632. 
sophistry. This unfair opinion is meant to have its origin in the fact that those opinion-makers either never studied the art of syllogism or studied it in a very bad way; they studied with bad teachers, they did not work hard enough or they are intellectually limited (sans intelligence) which undermines the credibility of those opinions.

\section{CONCLUSIONS}

Although both approaches are in line with modern preferences, relativising the meaning of traditional logic, which is transformed into a study of the method, or even into an outline of epistemology, they are eclectically inclined to validate the elements of logic defined since I. Kant's times as formal logic, even if only in a modest form. However, it is difficult to indicate which version of the Encyclopedia presents a more uniform line regarding the evaluation of logic. The Encyclopedia published by de Félice seems to be more moderate in modifying or even questioning the usefulness of the study of logic. However, it is not always consistent in this, and even sometimes exceeds the original edition with a modern tendency to reduce logic to the method of analysis. However, if one can find entries in the Encyclopedia, which, in a limited form, sustain the traditional theory of reasoning, even if in a simplified form, the interpretation of this reasoning, following e.g. the Port-Royal Logic, is not purely formal, since - as in Descartes - their value ultimately depends on the - subjectively understood - obviousness of first principles and relations between the elements of a chain of results that is closely related, even if defined in categories of deduction. Generally, however, one can see a preference for criticism of traditional logic, formulated in the spirit of empiricism as much in the theory of cognition as in the theory of science, especially in the case of Bacon, Locke and Condillac, but eclectically consistent with Descartes' methodology, which explains e.g. the common reference to Port-Royal Logic or, to a certain extent, to Wolff's achievements. However, the solutions adopted by both editions are closest to d'Alembert's eclectic approach. The preference for the method of scientific discovery over the method of lecture leads to relativisation of the rules of traditional logic, formulated to build 
a systemic structure of science, especially as the rules of traditional logic are replaced by the mathematical method. Again, however, the Encyclopaedia eclectically avoids its absolutisation and postulates its use either as validation of the synthetic method or as a chain of evidence characteristic of Euclid's geometry, or as a method of algebra associated with the analytical method, identified with procedures for scientific discovery.

\section{BIBLIOGRAPHY}

Arnauld A., Nicole P., La logique, ou l'art de penser contenat, outre les regles communes, plusieurs observations nouvelle propres à former le jugement, par le Sieur le Bon, Paris 1662.

Arnauld A., Nicole P., Logika, czyli sztuka myślenia, transl. S. Romanowa, Warszawa 1958.

Arndt H. W., Methodo scientifica pertractatum. Mos geoemetricus und Kalkülbegriff in der philosophischen Theorienbildung des 17. und 18. Jahrbunderts, Berlin 1971.

Boyer Argens J.-B. de, La philosophie du bon sens, ou reflexions philosophiques sur l'incertudine des connoissances humaines, à l'usage des cavaliers et du beau sexe, Paris 1737.

Buffier C., Les principes du raisonement exposés en deux logiques nouvéles avec des ramarques sur les Logiques qui ont eu le plus de réputation de notre temps, Paris 1714.

Condillac É., La Logique ou les premiers développements de l'art de penser, Paris 1780. Condillac É., Logika czyli pierwsze zasady sztuki myślenia, transl. J. Znosko, Warszawa 2011.

Condillac É., Logique, in: Oeuvres philosophiques de Condillac, vol. II, Parme 1754.

Crousaz J. P., Système de Reflexion qui peuvent contribuer à la nettetê et à l'étendue de nos connaissances, ou Nouvel Essai de Logique, Amsterdam 1712.

Descartes R., Oeuvres de Descartes, eds. C. Adam, P. Tannery, Paris 1897-1913.

Descartes R., Prawidta kierowania umystem, in: Prawidta kierowania umystem.

Poszukiwanie prawdy poprzez światto przyrodzone rozumu, transl. L. Chmaj, Warszawa $1958^{2}$.

Descartes R., Regulae ad directionem ingenii, Amstelodamii 1701.

Encyclopédie ou dictionnaire universel raisonné de connoissances humaines. Mis en ordre par M. de Félice, Vol. I-LVIII, Yverdon 1770-1780.

Encyclopédie ou dictionnaire universel raisonné des sciences, des arts et des métiers, par une societe de gens de lettres. Mis en ordre et publié par ... [Denis] Diderot et quant 
B la partie mathématique par ... [Jean le Rond] D'Alembert, Vol. I-XXXV, Paris 1751-1780; reprint: Stuttgart 1966-1995; electronic version: Marsanne 1999. Félice de F.-B., Leçons de logique, vol. I-II, Yverdon 1770.

Garewicz J., Kilka uwag o badaniu recepcji fllozofi, in: Wybrane zagadnienia z historii filozofii polskiej na tle filozoficznej umystowości europejskiej, ed. J. Legowicz, Wrocław 1979.

Genovesi A., Elementorum artis logico-criticae libri V, Venetiis 1745, Varsaviae 771. Historia matematyki od czasów najdawniejszych do poczqtku XIX stulecia, vol. II, in: Matematyka XVII stulecia, ed. A. P. Juszkiewicz, transl. S. Dobrzycki, Warszawa 1975, 90-107.

Howell W. S., Eighteenth-Century British Logic and Rhetoric, Princeton 1971.

Janeczek S., Jeszcze raz o dydaktyce logiki w oświacie Komisji Edukacji Narodowej. Ujęcie É.B. de Condillaca a przepisy i praktyka szkolna, in: W kierunku filozofi klasycznej inspiracje i kontynuacje. Ksiegga jubileuszowa ofiarowana Profesorowi Edwardowi Nieznańskiemu, eds. J. Krokos, K. Świętorzecka, R. Tomanek, Warszawa 2008, 471-483.

Janeczek S., Kartezjanizm teorii nauki É. Condillaca, in: Filozofia XVII wieku i jej kontynuacje, ed. Z. Drozdowicz, Poznań 2009, 203-209.

Janeczek S., Logika czy epistemologia? Historycznofilozoficzne uwarunkowania nowożytnej koncepcji logiki, Lublin 2003.

Janeczek S., Przejawy refleksji metafizycznej w fllozofi Étienne’a Bennota de Condillaca (1715-1780), in: Z dziejów filozoficznej refleksji nad cztowiekiem. Księga pamiątkowa ku czci Profesora Jana Czerkawskiego (1939-2007), eds. P. Gutowski, P. Gut, Lublin 2007, 257-274.

Janeczek S., Teoria nauki w ujęciu J. le Ronda d'Alemberta. Między empiryzmem, racjonalizmem i intuicjonizmem, in: Philosophia vitam alere. Prace dedykowane Profesorowi Romanowi Darowskiemu SJ, ed. S. Ziemiański, Kraków 2005, 199-212. Janeczek S., Z dziejów dydaktyki logiki w szkotach KEN. Claude Buffier SJ, Roczniki Filozoficzne 56(2008)2, 83-99.

Janeczek S., Z dziejów nowożytnej koncepcji logiki. J. le Rond d'Alembert, Roczniki Kulturoznawcze 4(2013)1, 51-82.

Janeczek S., Z dziejów nowożytnej koncepcji logiki. Od F. Bacona do É. Condillaca, Zeszyty Naukowe KUL (2009)3, 21-33.

Janeczek S., Z dziejów nowożytnej koncepcji logiki. Propagatorzy poglądów J. Locke’a, Kwartalnik Filozoficzny 36(2008)4, 95-110. 
Janeczek S., Źródta logiki Jana Śniadeckiego. F. Dalham's i I. Watts's textbooks, in: Gaudium in litteris. Księga pamiątkowa ku czci Księdza Arcybiskupa Stanisława Wielgusa, ed. S. Janeczek et al., Lublin 2009, 613-621.

Kuliniak R., Małysz T., XVII i XVIII-wieczne popularne podręczniki studiowania matematyki. With particular emphasis on "Krótki wyktad o matematycznej metodzie nauczania", in: Oblicza fllozofii XVII wieku, ed. S. Janeczek, Lublin 2008, 335-356.

Le Clerc J., Logica sive ars ratiocinandi. Logica, Ontologia, Pneumatologia, vol. I-II, Amstelodami 1692.

Le Rond d'Alembert J. B., Mélanges de littérature, d'histoire et de philosophie, Amsterdam 1759.

Locke J., An Essay Concerning Human Understanding, London 1690, actually 1689; quoted from: The Works of John Locke, London $1823^{3}$ (reprint: Aalen 1963), vol. III.

Locke J., Rozważania dotyczqce rozumu ludzkiego, transl. B. Gawecki, Warszawa 1955

Logika czyli pierwsze zasady sztuki myślenia, dzieto elementarne... na żqdanie bywszej Komisji Edukacyjnej Narodowej dla szkót publicznych napisane i od niej aprobowane, a teraz z przydatkiem niektórych objaśnień i przypisów przez Jana Znoskę z francuskiego na polski jezzyk przetożone, Wilno 1802, $1819^{3}$.

Makowski S. S., Cursus philosophicus iuxta veram Aristoetelis, philosophorum principis doctrina in alma universistate cracoviensi luci publicae porrectus, vol. I, Cracoviae 1769.

Risse W., Die Logik der Neuzeit, vol. II, 1640-1780, Stuttgart 1970.

Watts I., Logic, or the Right Use of Reason in the Inquiry after Truth with a Variety of Rules to Guard against Error in the Affairs of Religion and Human Life, as well as in the Sciences, London 1725 (reprint, published in London 1847 - Morgan, PA 1996).

Wolff Ch., Philosophia rationalis sive logica, methodo scientifica pertractatum ad usum scientiarum atque vitae aptata, Francofurti 1728 (edition of 1740 published by J. École'a - Hildesheim 1984).

\footnotetext{
Stanisław Janeczek

The John Paul II Catholic University of Lublin, Institute of Philosophy, Poland ORCID: https://orcid.org/0000-0003-3458-8634 janeczek@kul.lublin.pl
} 